аналитика: проблемы и решения: Научно-практический и информационноаналитический сборник. № 30 (216). М.: ИД «Финансы и кредит», 2014. С. 2-13.

2. Бурєннікова Н. В. $S E E$-управління на базі складових результативності як засіб підвищення дієвості процесу функціонування складних систем: сутність, методологія / Н. В. Бурєннікова, В. О Ярмоленко // Бізнес Інформ. - 2016. - № 1 - C. $145-152$

\title{
ЦИТ: ua117-058
}

DOI: 10.21893/2415-7538.2016-05-1-058

УДК 338

Зинькович Е.С.

ВНЕДРЕНИЕ ПРОЦЕДУР ЭКОЛОГИЧЕСКОГО МЕНЕДЖМЕНТА НА ПРЕДПРИЯТИЯХ ПИЩЕВЫХ ПРОИЗВОДСТВ С ТОЧКИ ЗРЕНИЕ ПОВЫШЕНИЯ УРОВНЯ КОНКУРЕНТОСПОСОБНОСТИ

Московский государственный университет пищевых производств, Москва, Волоколамское шоссе, 15, 125080

\section{IMPLEMENTATION OF ECOLOGICAL MANAGEMENT PROCEDURES AT THE ENTERPRISES OF FOOD PRODUCTION IN TERMS OF IMPROVED COMPETITIVENESS}

Moscow State University of Food Production

Moscow, Volokolamskoe avenue, 15, 125080

Аннотация: В работе рассматривается важность и сущиность процедур экологического менеджмента, их особенность использования для предприятий пищевых производств для повышения привлекательности предприятия $u$ улучшения его деловой репутаџии.

Ключевые слова: экологический менеджмент, международный стандарт в области систем экологического менеджмента, экологический аудит.

Abstract. In this paper we describe the essence and significance of ecological management procedures, their feature usage for food production to increase the attractiveness of the company and improve its reputation.

Key words: ecological management, international standards for ecological management system, ecological audit.

\section{Вступление.}

Экологический менеджмент как важная составная часть общего менеджмента в компании является неотъемлемой составляющей функционирования предприятия. Для предприятий пищевых производств экологическая составляющая и процесс внедрения процедур экологического менеджмента относится к приоритетным направлениям успешной деятельности предприятия.

\section{Основной текст}

В последнее время в мире стали уделять пристальное внимание вопросам экологической безопасности как производства в целом, так и выпускаемой продукции. Выпуск продукции согласно международным стандартам и 
требованиям качества, экологическим нормам и требованиям становится естественной нормой деятельности предприятий.

Соблюдение всех требований в области утилизации отходов и загрязнения окружающей природной среды является важным критерием соблюдения всех норм и требований.

Появление в 2005 году международного стандарта в области систем экологического менеджмента - ISO 14000 называют наиболее значимой из всех существующих международных природоохранных инициатив.

B ISO 14001:2004 и ISO 14004:2004 основное внимание уделено системам экологического менеджмента. Предприятие получает следующие преимущества от внедрения данных стандартов: снижение затрат на утилизацию отходов, экономия потребления энергии и сырья, улучшение имиджа среди стейхолдеров бизнеса, общества в целом. [1]

Что касается другого международного стандарта для пищевых предприятий в области производства безопасных пищевых продуктов - ISO 22000, то он также активно внедряется в процедуры экологического менеджмента отечественными предприятиями пищевых производств.

Данный стандарт предназначен для проведения сертификации систем менеджмента безопасности пищевых продуктов организаций, участвующих в цепи поставок, перерабатывающих или производящих: упаковку для пищевой продукции, пищевые ингредиенты, оборудование и очищающие средства. [2]

В Российской Федерации был принят национальный стандарт - аналог международному в системе менеджмента безопасности пищевой продукции, где описаны требования к организациям, участвующим в цепи создания пищевой продукции - ГОСТ Р ИСО 22000-2007.

Внедрение данного стандарта позволило унифицировать требования к влиянию и защите окружающей природной среды для всех предприятий в разных уголках земного шара. Также согласно данному стандарту предприятия имеют единый набор процедур и мероприятий, направленных на снижение нагрузки на окружающую среду, выпуск экологически чистой продукции, использование экологически чистой упаковки.

Предприятие получает следующие гарантированные преимущества от внедрения системы менеджмента безопасности: доверие потребителей и других стейкхолдеров бизнеса, возможность значительно расширить свои рынки сбыта, усилить инвестиционную привлекательность предприятия и увеличить конкурентоспособность выпускаемой продукции и самого предприятия.

Также все чаще на предприятиях используется система экологической безопасности. Другими словами, предприятие в систему общего менеджмента внедряет комплекс мероприятий в области природоохранных мероприятий, которые позволяют предприятию контролировать уровень своих выбросов и сбросов, повышают степень экологичности выпускаемой продукции и предприятия в целом.

В современном мире отечественные предприятия стали обращаться к процедуре экологического аудита. Аудиторская проверка в области соблюдения всех экологических норма и требований может быть обязательной или 
добровольной. Данная инициатива позволяет предприятиям выявить прошлые и существующие экологически значимые проблемы и принять необходимые меры по их устранению или минимизации нагрузки на окружающую природную среду.

Благодаря регулярным аудиторским проверкам предприятие может повысить свою инвестиционную привлекательность; снизить риск возникновения различных чрезвычайных ситуаций, связанных с загрязнением окружающей среды; сертифицировать систему экологического менеджмента предприятия на соответствие стандарта ISO 14001; сформировать экологическую стратегию предприятия; выйти на международный рынок, укрепить свои позиции на остро конкурентном рынке. Наконец, повысить уровень своей конкурентоспособности и степень лояльности потребителей к своему бренду. Считается, что проведение экологического аудита - это самый короткий путь к экологически безопасному бизнесу.

Также следует отметить, что сами процедуры экологического менеджмента и процесс их внедрения относятся к программам социальной ответственности предприятия.

Компании постоянно находятся в поиске источников основных ресурсов для обеспечения надлежащего качества выпускаемой продукции, eе безопасности и экологичности.

В рамках корпоративной социальной ответственности огромное внимание уделяется механизмам повышения стандартов производственной деятельности; вопросам снижения и управления рисками для обеспечения безопасности пищевых продуктов; процедурам совершенствования экологических стандартов.

Подобные инициативы позволяют компаниям выделиться на фоне своих конкурентов, привлечь дополнительные инвестиции и капиталовложения, внимание общества к своей деятельности, тем самым, повысить и привлекательность своего товара, и возможно, пролоббировать свои интересы на более высоком уровне.

Выводы. Подводя итоги, отметим, что отечественные предприятия активно внедряют процедуры экологического менеджмента в общую стратегию и политику своего развития. Данные процедуры позволяют предприятиям не только улучшать свой имидж и деловую репутацию, повысить уровень конкурентоспособности предприятия и выпускаемой продукции, но и расширять масштабы своей деятельности, выходя в качестве полноценного участника на международный рынок, равноправно конкурируя с известными игроками отрасли.

Список литературы:

1.www.iso-22000.ru - Сертификация по стандарту качества ISO -22000 (HACCP)

2.www. iso.org-Стандарты на системы менеджмента

Статья отправлена: 01.04.2017

(C) Зинькович Е.С. 